\title{
Innovation of Supply Chain Finance Model in Agricultural Engineering A Case Study of the Apples Wholesale Market in Qingyang, Gansu Province
}

\author{
Erzhong $\mathrm{Xu}^{1 \mathrm{a}}$,Xing $\mathrm{Li}^{1 \mathrm{~b}^{*}}$ \\ ${ }^{1}$ LongDong University ,QingYang City,Gansu 745000,China; \\ axez1964@126.com, bleebj@189.cn*
}

\section{Keywords: Agricultural Engineering; Supply chain; Qingyang; Apple planting}

\begin{abstract}
The large-scale development of modern enterprises, especially modernization of agricultural engineering is inseparable from the support of the financial industry. Supply chain finance has a particularly important position in agricultural engineering. This paper based on modern agricultural supply chain proposed a new model to develop agricultural supply chain finance with the central wholesale market in "hub" engineering as the core and explained the model by taking the Apples Wholesale Market in Qingyang, Gansu Province for example. Not only is the new model more efficient than the original model, but it is also a supplement to the original model. The new model is intended to lead more interests to the apple growers to benefit them.
\end{abstract}

\section{Introduction}

Agriculture is an important part of the national economy, and the advantages of modern agricultural engineering are obvious to all. The development of modern agricultural engineering requires not only innovation of science and technology but also financial support and innovation. Finance-aided agricultural development is one important manifestation of finance as the core of modern economy. Financial innovation also provides a variety of options for how to deliver financial support to agricultural development. Currently, the first problem facing China's agricultural development is the lack of financial support, mainly reflected as financing difficulties for agricultural SMEs and farmers, while supply chain finance provides an effective way to solve this problem. Supply chain finance is aimed at the credit status of the entire supply chain, which relying on the core enterprises in the context of the real transactions of specific products enhances the credit level of SMEs and farmers, reduces financing costs and risks, and thus is conductive to the conduct of financial services.

Supply chain finance refers to activities of transaction financing and pricing of related services people carry out in order to meet the financial needs of supply chain-based production organization systems. In general, supply chain finance emerges after a certain industry generates a complete industrial chain or a more complete form of industrial chain, and then it is carried out centering core enterprises at the prominent links in the industrial chain. Supply chain finance is an innovation of financial service modes that can effectively address the model needs for financial support to agricultural development. Agricultural supply chain finance refers to systemic solutions centered at core enterprises of the supply chain of featured agriculture and advantageous agricultural produce that bundle the interests of the upstream and downstream SMEs, farmers or consumers of the core businesses and meet the financing needs of all aspects of the supply chain by financial products based on scientific and rational design so as to promote the overall coordinated operation of the agricultural supply chain.

Agricultural supply chain finance has now developed into an important measure used by a number of developing countries to reduce farmers' exclusion of finance and expand the coverage of finance in rural areas. The related financial institutions have carried out product and service innovation specifically around agricultural supply chain finance. Based on learning from business models abroad, some of China's financial institutions (such as the Agricultural Bank of China, Qingyang's local Credit 
Union and Ruixin County Bank, etc.) according to the status of agricultural development combined with localization features of agricultural development in relevant regions launched the following modes of supply chain financial services: companies + farmers, companies + specialized cooperatives / bases / leading specialized households + farmers, leading specialized households + farmers, etc. This shows that different modes have different driving force. Some see companies (including leading enterprises) as the core, while others see specialized cooperatives as the core \#. However, all modes are implemented by support, participation and organization of financial institutions, occupying an important position in the industrial chain, playing a role in stabilizing production-sales contact, organization, management and control of the whole industry chain, thus meeting the requirements of supply chain finance for core businesses, though the modes have not been put in reasonable use in supply chain finance. In this regard, this paper built a financing model connecting 'banks, agricultural products wholesale markets, market brokers, private brokers, farmers, and governments' as a new breakthrough in the development of agricultural supply chain finance.

\section{Research theory and model}

Agricultural chain is a process from seed to table, including cultivation \$ procurement of means of production and field management, agricultural production, acquisition of agricultural products, processing, distribution, wholesale and terminal retail. In general the chain involves providers of means of production, farmers, brokers (cooperatives), transport and logistics providers, processing enterprises, wholesale markets, retail markets and consumers who are bundled together by relation between supply and demand and interest mechanism. Based on China's reality, the whole process of agricultural industry chain is shown in Figure 1. The agricultural supply chain is a more complex system than the agricultural industry chain, which highlights the central position of the core businesses, using the control of information flow, material flow, and capital flow to link the SMEs, farmers, and end-users of the industry chain associated with the core businesses together into a whole functional network chain structure. The model of agricultural supply chain finance is shown in Figure 1

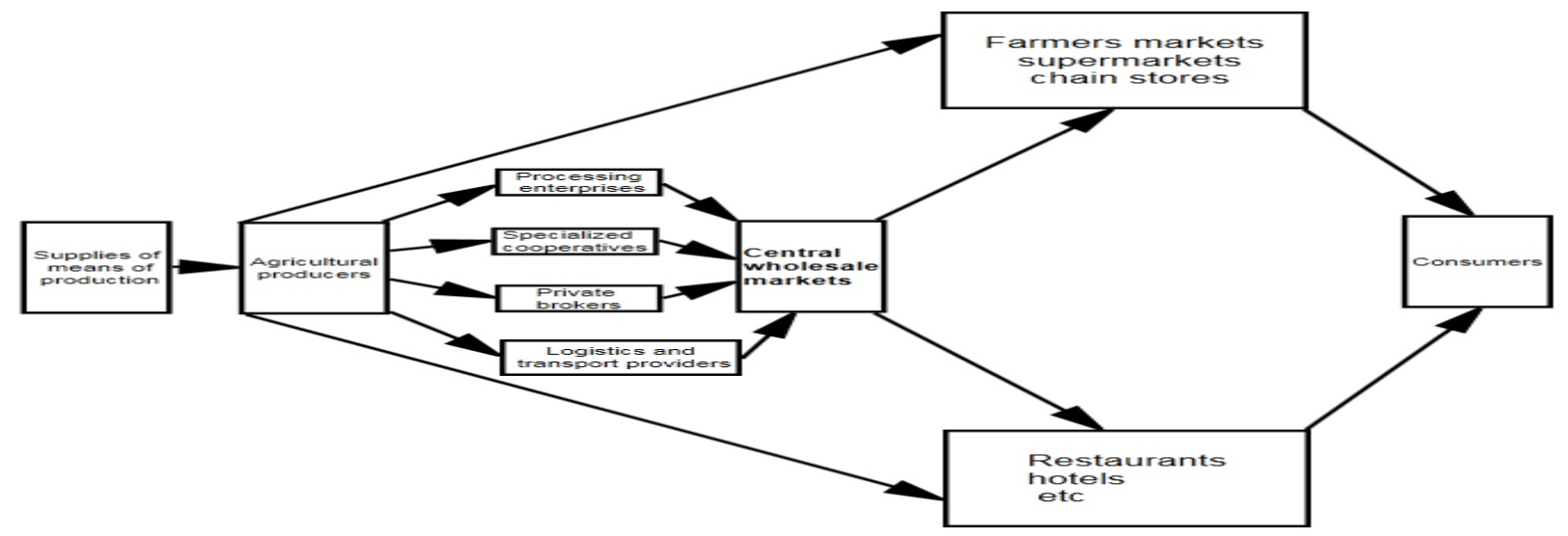

Figure. 1 Agricultural Industrial Chain Flow Chart

Industrial chain and supply chain are similar and interrelated, but comparison of the two shows that the biggest difference is that the industrial chain does not reflect the position of the core businesses, while the supply chain is carried out around the core businesses, while making clear the requirements for management and control of capital flows. Moreover, the supply chain is differentiated from the industry chain, and the industry chain is the foundation that gives rises to supply chain. The supply chain is flexible transformation and use of the industry chain, while the new model is extracted from the original industry chain in accordance with the requirements of the supply chain, whose main difference from existing models is the change of core businesses. Specially, the existing models capture the core businesses in two aspects of processing and production, i.e. mainly using agricultural products processing enterprises and specialized cooperatives or bases as the driving force to carry out 
the supply chain finance, while the new model uses the central wholesale market in vegetable basket project as the core, using its unique organizational model - merchants settled in the market for operation - to conduct supply chain finance.
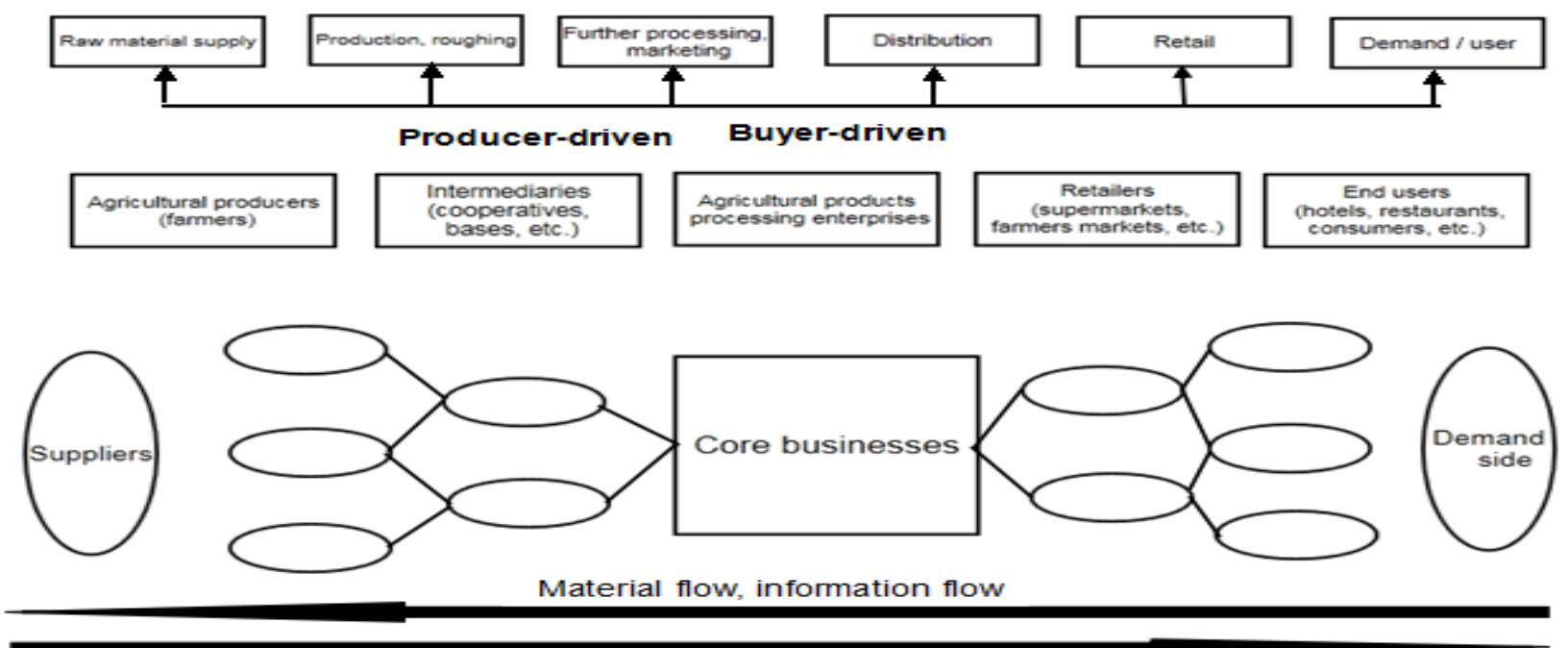

Capital flow, information flow

Figure. 2

From the perspective of the central wholesale market, after obtaining the resources and advantages to serve as the core enterprise, its main purpose or advantage to develop supply chain finance based on cooperation with financial institutions is by meeting the demand for financial services of market merchants and private brokers in close cooperation with them and the majority of farmers to help the market from a brand effect in order to stabilize the existing merchants and attract more merchants to enter, thereby reducing the cost of operation, increase the profitability, and ultimately achieve efficient operation of the market, further expand its influence to develop quality service into a competitive advantage. In particular, given the current fierce competition between wholesale markets and the limitation of merchant resources, it is very necessary for wholesale markets to introduce supply chain finance.

Below is a detailed description taking the apples wholesale market in Qingyang, Gansu Province for example. The main players in the agricultural supply chain include farmers, private brokers, market merchants, financial institutions, logistics companies, etc. Its basic financing infrastructure is shown in Figure 3 .

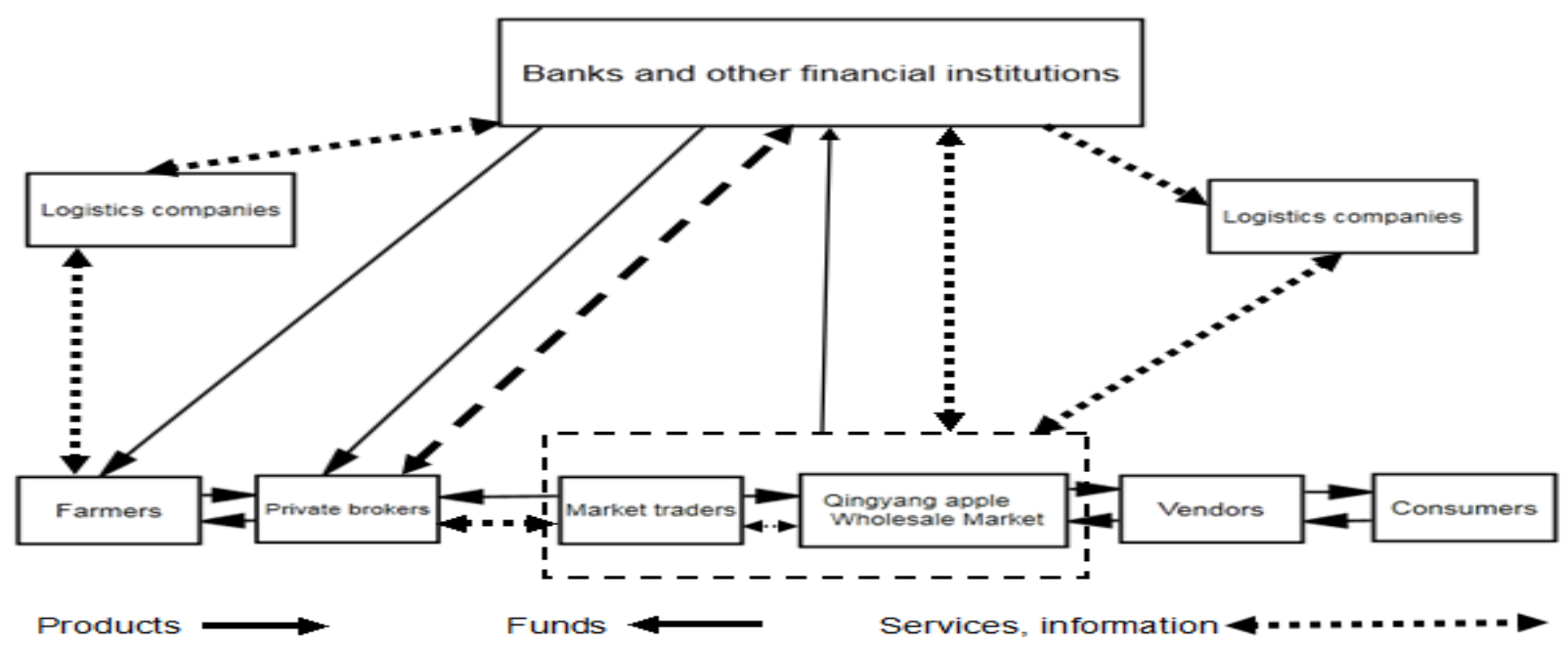

Figure. 3 
Components and role positioning of the new model in agricultural supply chain finance: financial institutions refer to institutions based on willingness to take some risks to provide SMEs and farmers of the supply chain with financial services, mainly referring to the banks. From the macro level, the agricultural supply chain finance requires financial institutions to take the initiative in strengthening cooperation and communication with the central wholesale market, logistics companies, and local government, developing supply chain financial services, and taking effective risk control measures to eventually achieve a win-win in meeting the financing needs of SMEs and farmers. From the micro level, financial institutions must consciously grasp the content and direction of capital flow, information flow, and material flow. If the funds, services, and information flow like water, financial institutions play the role as a staging area - a transit point with the main purpose to ensure the smooth running and timely reflux of the water in the whole chain.

Agricultural supply chain finance model using wholesale center for circulation has been developing for many years. There are usually familiar, trusted and stable cooperative relations between the market merchants and private brokers, which creates the conditions to implement recommendation system and carry out the supply chain. Led by financial institutions, with the support of all levels of government, all players actively cooperate and seize two aspects to provide supply chain financing: one is to meet the financial needs of the production link, which takes three forms:

First, private brokers (market merchants) + farmers: private brokers may cooperate with market merchants to provide farmers, such as quality apple orchards, with trade credit in such forms as selling means of production on credit. In this process, there will be a verbal agreement of purchase and sale, under which until the harvest farmers are willing to sell agricultural products to private brokers or market merchants who by then will sign a formal purchase and sales contract with farmers, and after the acquisition the settlement will deduct the costs of means of production sold on credit, but if farmers are willing to sell themselves, the market merchants will not forcibly acquire the farmers' agricultural products.

Second, wholesale market + merchants + private brokers (farmers): the wholesale market can invite financial institutions to enter and do matchmaking between the financial institutions and market merchants. The financial institutions after overall credit assessment of merchants in the market sign a letter of intent with merchants with good credit. The market merchants are responsible for recommending to financial institutions private brokers or farming households with certain planting scale, who are generally those in long-term business relationship with the merchants, so that the market merchants are willing to provide loan guarantees and the two sides sign formal purchase and sale contracts to strictly stipulate the planting varieties, quantity and time of acquisition. The recommended private brokers and farmers then voluntarily apply for loans, and the financial institutions after reviewing their credit status will issue the loans \#. Until the agricultural products are released to market, under the premise that the parties have fulfilled the purchase and sale contract, market merchants will pay the purchase price through financial institutions, and financial institutions after deducting the loan principal and interest will transfer the money to the designated account.

Third, wholesale market + merchants + private brokers + farmers: In order to expand the number of benefited farmers, the recommended private broker can organize local dispersed farmers in the form of voluntary joint guarantee groups composed of farming households. These households will enter into a joint guarantee agreement, under which the members assume joint responsibility for the loans for each other. As recommended by private brokers the members apply for loans to financial institutions. In addition to the land management interests as collateral, the farmers can also sign a purchase and sales contract with private brokers and market merchants and mortgage the contract to obtain loans.

Another form is for the sales link, mainly to meet the demand for funds of private brokers and market merchants \#. In order to ensure stable and sustainable supply of agricultural products market merchants will sign a certain number of orders. These orders are directly from farmers or private brokers acting as intermediate buyers. At this time, either market merchants or private brokers are likely to suffer cash shortages \#. In particular, for private broker, without enough financial support, 
they will not sign more orders, which may result in missing the best timing to market the agricultural products, thereby triggering the subsequent default by farmers. So under the circumstances that market merchants and private brokers respectively provide guarantee by collateral or jointly provide guarantee, taking into account the quantity and quality of orders and market conditions, financial institutions can flexibly handle the loan amount, but implement strict regulations over the term and the repayment time of the loans. As it is difficult to predict vegetable market conditions, the loan period shall not be too long, and since the loans are mainly to meet capital flows needs of market merchants and private brokers, financial institutions should ensure the controllability of risks.

In the specific operation, in whichever mode the financing must comply with the characteristics of supply chain finance: closure, self-liquidation and continuity. The specific manifestations are first, the receipt and payment of loans and purchase prices are completed by financial institutions to ensure that control of capital flow \#; second, the repayment of the loans should come from the cash flow generated from the future transactions in the chain. The financial institutions should join local governments to implement regulation and ensure the earmarked use of the loans; finally, under the recommendation system the credit rating of private brokers and farmers is linked with the market merchants, prompting market merchants to pick the most qualified and highly creditable private brokers and farmers to ensure the successful completion of transactions and the continuity of the loans; or the entire market is used as the evaluation criteria to divide the borrowers, so that different levels of borrowers are given different sizes of loans, prompting the wholesale market to actively participate in the financing. In addition, whether it is for market merchants, private brokers, logistics companies or farmers, financial institutions should join the wholesale market and local township government to investigate their credit status and fulfilling capability, such as the market merchants' relevant experience, income in the past few years, and the stability of their source of income, and collateral (house, shop deposit) valuation; farmers' planting experience, planting gains in the past few years, credit rating of individual farmers, credit record (where there is a bad record or default), land use right proof verification, mid-term evaluation (field trips) and so on.

\section{Conclusion}

The development of agricultural supply chain finance requires each participating subject to from the starting point of the entire supply chain give play to their respective advantages and complement each other to ensure the smooth running of information flow, capital flow and material flow in the supply chain; to unite all forces that can be united to ensure the continuity of the supply chain. The bilateral, trilateral or multilateral cooperation is essential. In initial operation of the new model, cooperation between financial institutions and the central wholesale market is fundamental; in credit assessment the wholesale market, market merchants, private brokers, and farmers should be tied together; the lending should be carried out around those with financial needs; in case of default of the loan, multiple participants should form a coalition against the defaulter. In addition, the governments and the insurance companies are the principal founders and implementers of peripheral risk protection mechanisms \#. The new model has the biggest characteristic of strong reproducibility. The financial institutions should actively approach these wholesale markets to provide supply chain financial services for agriculture. Once the model is really implemented, the range of radiation will become broader, the inter-market relationship closer, the transmission of information quicker and more efficient, logistics tracking also more convenient; and most importantly, more farmers will be motivated, so that farmers become the real beneficiaries.

\section{References}

[1] Beamon, B. M. (1999). Measuring supply chain performance. International Journal of Operations \& Production Management, 19(3), 275- 292. 
[2] Bourgeois, L. J. III (1980). Strategy and environment: A conceptual integration. Academy of Management Review, 5(1), 25- 39.

[3] Christopher, M. (2000). The agile supply chain: Competing in volatile markets. Industrial Marketing Management, 29(1), 37-44.

[4] Li,Xing;Chen,Liu,Research on radio frequency identification influence factors of enterprises,IWECA 2014,pp.740-742 .dio: 10.1109/IWECA.2014.6845728

[5] Lawrence, P. R., \& Lorsch, J. W. (1967). Organization and environment: Managing organization differentiation and integration. Boston, MA: Harvard University Press

[6] Porter, M. E. (1980). Competitive strategy. New York, NY: Free Press

[7] Fisher, M. L. (1997). What is the right supply chain for your product? Harvard Business Review, 75(2), 105- 116.

[8] Woodside, A. G. (2010). Case study research: Theory, methods and practice. Bingley, UK:Emerald Group Publishing Limited. 